\title{
BERBAGAI TEORI MENGENAI PERKEMBANGAN TEKNOLOGI
}

\author{
Masykur Wiratmo \\ Fakultas Ekonomi Universitas Gadjah Mada
}

\begin{abstract}
Abstrak
Perubahan lingkungan kompetisi membuat fokus perkembangan teknologi dan besarnya peranan pemerintah di masing-masing negara menjadi berlainan. Negara-negara industri secara umum memfokuskan dan berlomba-lomba untuk mencapai batas-batas inovasi mereka, dan mencoba untuk memperbaiki sistem inovasi nasional. Disisi lain, negara-negara berkembang pada umumnya lebih fokus untuk mengadaptasikan teknologi yang ada secara lebih efektif.

Pengamatan proses industrialisasi jelas tidak bisa mengabaikan arah perkembangan teknologi. Dengan demikian teori-teori mengenai teknologi menjadi sangat relevan kalau para peneliti mengenai industrialisasi ingin memperoleh gambaran yang baik mengenai proses-proses yang berlangsung. Ketertinggalan negara sedang berkembang dalam bidang ekonomi sebenarnya dapat ditelusuri dari ketertinggalan di bidang teknologi ini.
\end{abstract}

\section{PENDAHULUAN}

Dekade 1960 sampai dengan dekade 1980 merupakan periode yang sangat produktif bagi teori-teori baru dan pengetahuan empiris tentang sumber-sumber perubahan teknologi. Pada dekade 1960-an dan 1970-an perhatian difokuskan pada implikasi dari perubahan permintaan dan harga-harga relatif pada tingkat dan arah perubahan teknologi. Pada akhir dekade 1970-an dan awal 1980-an perhatian bergeser ke model evolusioner (evolutionary model) yang terinspirasi oleh munculnya ketertarikan pada pandangan-pandangan Schumpeter mengenai proses pembangunan ekonomi. Sejak awal dekade 1990-an teori sumber-sumber perubahan teknologi dilengkapi dengan perkembangan model yang berbasis sejarah, yaitu model "jalur ketergantungan" (path dependent) perubahan teknologi (Ruttan, 1997:1520).

\section{INDUCED TECHNOLOGICAL CHANGE}

Teori ini berpendapat bahwa perubahan teknologi disebabkan oleh faktor-faktor ekonomi lain, seperti perubahan faktor, permintaan dan pertumbuhan (Dixon, 1997: 1518). Dalam teori induced technological change, menurut Ruttan (1997:1520-1526), ada tiga tradisi utama yang mencoba untuk mengkonfrontasikan dampak-dampak perubahan dalam lingkungan ekonomi terhadap perubahan tingkat atau arah perubahan 
teknologi. Tiga tradisi tersebut, sebagaimana direview oleh Ruttan, adalah sebagai berikut:

- Pertama, tradisi tarikan permintaan (demand pull), yang menekankan pentingnya perubahan permintaan pasar terhadap pengetahuan dan teknologi. Griliches (1957) menunjukkan peran permintaan dalam menentukan waktu dan lokasi penemuan. Schmooker $(1962,1966)$ menyimpulkan bahwa permintaan lebih penting dalam mendorong penemuan daripada kemajuan ilmu pengetahuan.

- Kedua, tradisi teori pertumbuhan atau ekonomi makro. Tradisi ini muncul dari perdebatan pada awal 1960-an mengenai alasan stabilitas dalam pangsa faktor pada kondisi tingkat kenaikan upah yang sangat cepat. Keterbatasan utama dari versi teori pertumbuhan ekonomi adalah batas kemungkinan inovasi (Innovation Possibility Frontier) yang tidak masuk akal Menurut Kennedy, bentuk dari Innovation Possibility Frontier tidak tergantung pada bias jalur perubahan teknologi. Selama perubahan teknologi tidak ada efek trade off antara perubahan teknologi yang disebabkan tenaga kerja dan kapital.

- Ketiga, tradisi ekonomi mikro. Model mikro dibangun pada awal pengamatan yang dilakukan oleh Hicks. Hicks mengatakan bahwa perubahan relatif harga faktor-faktor produksi mendorong inovasi dan penemuan sesuatu yang diarahkan pada penggunaan faktor yang digunakan relatif lebih mahal menjadi ekonomis (Hicks, 1932: 124-5). Model ini digerakkan oleh perubahan eksogen dalam lingkungan ekonomi dimana perusahaan-perusahaan atau agen riset publik menemukan perubahan eksogen tersebut oleh diri mereka sendiri. Model ekonomi mikro dihasilkan oleh sejumlah besar penelitian empiris dan bermanfaat untuk mengklarifikasi proses historis suatu perubahan, terutama pada tingkat industri atau sektor di dalam atau antar negara (Hayami and Ruttan, 1970, 1971, 1985; Binswanger, 1974; Binswanger and Ruttan, 1978; Thirtle and Ruttan, 1987). Kelemahan utama dari model ekonomi mikro adalah bahwa mekanisme internalnya - mempelajari, meneliti, dan proses formal R\&D - masih tetap di dalam "kotak hitam".

\section{TEORI EVOLUSIONER (EVOLUTIONARY THEORY)}

Kekuatan model evolusioner terletak di area dimana model ekonomi mikro induced innovation paling lemah. Model ini menciptakan teori perilaku perusahaan untuk memberikan deskripsi yang lebih realistik mengenai cara bekerja di dalam "kotak hitam". Pada awalnya model evolusioner didominasi oleh pola-pola atau rutinitas aktivitas produksi, aksi 
individu, penentuan kombinasi produk, ekspansi pabrik, dan R \& D. Pada model selanjutnya, Nelson dan Winter mengembangkan proses "mencari dan seleksi" yang memasukkan, setidaknya secara terbatas, elemen pilihan rasional (Nelson dan Winter, 1982:14). Model evolusioner mengatakan ada suatu jalur perubahan teknologi yang apabila ada pergeseran yang sama pada harga relatif tidak akan menghasilkan jalur yang sama dengan model ekonomi mikro neoklasik induced innovation (Nelson dan Winter, 1975: 466-86).

Dua mekanisme mendasar dalam model Nelson dan Winter, sebagaimana yang dikutip oleh Vernon W. Ruttan (1997:1522) adalah: (1) Pencarian teknologi yang lebih baik; (2) Seleksi inovasi melalui pasar. Menurut Nelson dan Winter, perubahan teknologi dapat terjadi karena pencarian inovasi-inovasi teknologi secara lokal, imitasi hal-hal yang dilakukan perusahaan lain, dan pemuasan perilaku ekonomi.

Model evolusisioner memahami pasar sebagai sesuatu yang secara sosial merupakan lingkungan terseleksi yang mengistemewakan bertahannya jenis teknologi tertentu (Walsh, 1993). Namun model evolusioner lebih menekankan pada karakteristik perilaku perusahaan (Saviotti dan Metcalf, 1991). Analisa dari model evolusioner mewarisi komitmen Schumpeterian secara radikal maupun inkremental mengenai perubahan-perubahan dalam proses dan produk. ${ }^{1}$

\section{TEORI JALUR KETERGANTUNGAN (PATH DEPENDENCE THEORY)}

Kekuatan model jalur ketergantungan terletak pada pandangannya mengenai pentingnya tahapan-tahapan spesifik dalam peristiwa historis pada tingkat mikro. Dalam pandangan ini, teknologi yang dipilih sekarang menjadi penghubung dan mempengaruhi dimensi masa depan teknologi dan pengetahuan. Meskipun demikian, konsep technological lock in, setidaknya di tangan para praktisi yang lebih kaku, diaplikasikan hanya pada teknologi yang mempunyai karakter skala hasil yang meningkat. Pada industri dengan skala hasil yang konstan atau menurun, historical lock in tidak berlaku.

\section{TEORI UMUM TENTANG PERUBAHAN TEKNOLOGI}

Ruttan (1997:1524-1526) berpendapat bahwa ketiga pendekatan yang telah dipaparkan di atas (induced technical change theory, evolutionary theory, dan path dependence theory) sedang mendekati jalan buntu.

1 Dibahas secara luas dalam R. Williams and D. Edge, 1996, "The social shaping of technology", Research Policy, Vol. 25, No. 6, September, hal. 871-865-866. 
Menurutnya, diperlukan suatu "jembatan" untuk menghubungkan tiga pendekatan yang terpisah untuk meningkatkan pemahaman mengenai sumber-sumber perubahan teknologi.

Menurut Ruttan, ada beberapa langkah untuk membuat teori umum mengenai perubahan teknologi, yaitu:

1) Langkah pertama adalah mengintegrasikan model dorongan faktor dan model dorongan permintaan.

2) Langkah kedua adalah mengintegrasikan model dorongan perubahan teknologi dan model jalur ketergantungan. Dari perspektif historis, isunya diletakkan pada bagaimana elastisitas substitusi berubah sepanjang waktu dalam merespon perubahan sumber daya endowmen atau harga faktor relatif, dan bagaimana ketergantungan jalur perubahan teknologi terhadap kondisi awal ketika suatu "pintu gerbang teknologi" muncul.

3) Langkah ketiga adalah mengintegrasikan antara teori dorongan perubahan teknologi, teori jalur ketergantungan, dan teori perdagangan internasional. Faktor endowmen relatif memainkan peranan penting dalam teori perdagangan Heckscher-Ohlin dan teori dorongan perubahan teknologi. Di bawah asumsi H-O masing-masing negara mengekspor komoditi yang intensif faktor berlimpah. Dorongan perubahan teknologi bertindak untuk membuat faktor yang langka lebih berlimpah.

\section{PANDANGAN NEO-KLASIK TENTANG TEKNOLOGI}

Ekonom Neo-klasik mempunyai pendekatan "instrumental" dalam mengamati teknologi. Mereka cenderung berasumsi bahwa teknologi dapat dipesan kapan saja diminta oleh pasar (Coombs et al., 1987). Dalam pandangan neo-klasik, pengembangan teknologi dianggap mempunyai fleksibilitas yang tinggi dan tersedia bagi siapa saja. Mereka mengabaikan keterputusan inovasi. Bentuk dan isi teknologi tidak mendapat perhatian yang detil oleh ekonom neo-klasik (David, 1975; Coombs et al., 1987; MacKenzie, 1992; Lundwall, 1993; Rosenberg, 1994).

\section{PENDEKATAN SEJARAH TENTANG TEKNOLOGI}

Pendekatan sejarah menekankan pada ketidaksamaan proses perkembangan industri dan teknologi, keterputusannya, serta perubahanperubahan kualitasnya. Perubahan-perubahan dalam teknologi-teknologi dasar telah memainkan peranan kunci dalam pendekatan sejarah, misalnya oleh Freeman yang menggunakan kerangka 'post Schumpeterian'. 
Sebagian besar studi dengan pendekatan sejarah dilakukan pada tingkat yang sangat umum, mencoba menerangkan pola jangka panjang dalam inovasi dan aktivitas ekonomi (Freeman et al., 1982; Perez, 1983). Untuk menerangkan pola-pola dalam bentuk pergeseran paradigma teknoekonomi, terutama gagasan Kuhnian tentang 'paradigma', pendekatan sejarah meminjam ide dari ilmu sosiologi Analisa sejarah mengenai teknologi menekankan pada interaksi antara penawaran (yaitu "dorongan ilmiah") dan permintaan, yang dipahami sebagai proses yang saling kontradiktif dan bukan yang satu menentukan yang lain. Pendekatan sejarah beberapa diantaranya mendapat kritikan mengenai kecenderungannya memperlakukan teknologi secara sangat umum, dan kadangkadang melihat perubahan teknologi sebagai penggerak dari perubahan sosial-ekonomi. Para sejarawan ekonomi mendeskripsikan pertumbuhan dunia sebagai penyebaran kemajuan secara gradual dari inovator-inovator kecil. Negara inovator merupakan negara yang paling produktif, namun inovasi mereka juga mendorong pertumbuhan di mana-mana. ${ }^{2}$

\section{Evolutionary Model Of Innovation}

Model inovasi evolusioner memahami pasar sebagai sesuatu yang secara sosial merupakan lingkungan terseleksi yang mengistemewakan bertahannya jenis teknologi tertentu (Walsh, 1993). Model evolusi lebih menekankan pada karakteristik perilaku perusahaan (Saviotti dan Metcalf, 1991). Analisa dari model inovasi evolusioner mewarisi komitmen Schumpeterian secara radikal maupun inkremental mengenai perubahanperubahan dalam proses dan produk.

\section{Social Shaping Of Technology}

Pendekatan social shaping of technology (SST), sebagaimana dijelaskan oleh Williams dan Edge (1996: 871, 865, 868), sangat kontras dengan pendekatan tradisional yang hanya membahas dampak dari perubahan teknologi. Pendekatan SST menguji isi dari teknologi dan proses-proses tertentu yang terlibat dalam inovasi. Di samping itu, para penganut pendekatan SST melakukan eksplorasi serangkaian faktor-faktor yang membentuk pola desain dan implementasi dari suatu teknologi, misalnya faktor organisasi, politik, ekonomi dan budaya. Manfaat dari pendekatan ini adalah menawarkan pemahaman hubungan antara kemajuan ilmiah, inovasi teknologi dan ekonomi serta kehidupan sosial.

\footnotetext{
2 Nathan Rosenberg, 1982, Inside the Black Box; Technology and Economics, New York, cambridge University Press, 247, dikutip dari Jonathan Eaton and Samuel Kortum, 1999, "International Technology Diffusion: Theory and Measurement", International Economic Review, Vol. 40, No. 3, hal. 537-538.
} 
Pendekatan ini bermanfaat untuk memperluas agenda kebijakan, misalnya dalam mempromosikan dan memanajemen perubahan teknologi.

Pendekatan SST timbul dari adanya kritik-kritik terhadap penentuan teknologi secara kasar, yang beranggapan bahwa sifat teknologi dan arah perubahan tidak mempunyai persoalan dan ditentukan sebelumnya, serta teknologi menentukan dampak terhadap pekerjaan, kehidupan ekonomi, dan masyarakat secara keseluruhan. Dengan kata lain, perubahan teknologi membuat perubahan sosial dan organisasi. Studi-studi dengan pendekatan SST menyelidiki cara-cara dimana faktor-faktor masyarakat, institusi, ekonomi dan budaya telah membentuk arah maupun kecepatan inovasi, bentuk teknologi, dan hasil-hasil perubahan teknologi untuk kelompok-kelompok yang berbeda di masyarakat (Williams dan Edge, 1996: 871-868).

\section{TEORI PERDAGANGAN BERORIENTASI TEKNOLOGI}

Dua dekade terakhir berkembang teori perdagangan berorientasi teknologi untuk menjelaskan pola perdagangan dan investasi di industriindustri tertentu dimana perbedaan teknologi sangat penting. Secara umum teori ini menekankan pada perubahan teknologi dan akibatnya terhadap pola perdagangan produk-produk baru. Berikut ini akan diuraikan tiga model perdagangan berorientasi teknologi yang dikemukakan oleh Posner (1961), Hirsch (1967), dan Vernon (1966). ${ }^{3}$ Berikut ini akan dipaparkan perkembangan teori perdagangan berorientasi teknologi menurut tulisan Deardorff (1996: 493-495).

\section{Posner: Model Kesenjangan Teknologi}

Posner (1961) tergolong yang pertama yang secara teoritis berusaha menerangkan pola perdagangan dari sisi kemajuan teknologi. Model kesenjangan teknologi yang diciptakan Posner merupakan generalisasi dari model Ricardian. Perdagangan berlangsung karena perbedaan antar negara dalam hal teknologi.

Model Posner merupakan hasil pengamatan Posner tentang proses dinamis perkembangan suatu produk, yang dijelaskan sebagai berikut. Selama proses dan produk baru terus-menerus dikembangkan, negara dimana inovasi tersebut berlangsung untuk sementara waktu akan menikmati keuntungan dari kemajuan teknologi dibanding negara mitra dagangnya. Keunggulan ini akan berakhir ketika teknologi baru ini ditiru

3 Alan V. Deardorff, 1996, "Testing Trade Theories and Predicting Trade Flows", dalam R.W. Jones and Peter B. Kenen (eds.), Handbook of International Economics, International Trade, Elsevier, Amsterdam, hal. 493-495. 
negara lain, dan sebelum teknologi baru ini ditiru negara lain, negara yang melakukan inovasi dapat mengekspor produk baru tersebut meskipun tidak mempunyai basis keunggulan komparatif dari segi faktor endowmen maupun intensitas faktor. Dengan berjalannya waktu, inovasi menyebar ke seluruh dunia dan keunggulan yang pada awalnya diterima menghilang. Keunggulan yang dimiliki negara inovator akan tetap diperoleh jika kemajuan teknologi terus berlangsung dan penemuan-penemuan baru terus dibuat serta selalu ada perubahan produk-produk baru dimana negara yang melakukan inovasi memperoleh keunggulan komparatif.

Kontribusi yang diberikan Posner adalah menjelaskan proses dinamis dimana kemajuan teknologi terus menerus diperbaharui pada produk-produk yang berbeda, dan pada saat yang sama teknologi yang ada ditransfer ke negara- negara lain. Salah satu kelemahan dari model kesenjangan teknologi adalah model ini gagal untuk menerangkan mengapa suatu inovasi, pada saat ditemukan pertama kali, tidak mendapat keunggulan di lokasi yang mempunyai biaya paling rendah. Alasannya cukup mudah dipahami bahwa pihak yang melakukan inovasi akan menolak untuk membagi pengetahuannya kepada yang lain.

\section{Hirsch: Siklus Teknologi}

Hirsch (1967), yang mengikuti pemikiran Kuznets (1953), berpendapat bahwa produk-produk baru akan melewati suatu siklus perubahan sistematis dalam teknologi. Produk-produk baru pada awalnya membutuhkan sejumlah besar tenaga kerja terampil untuk produksi dan perkembangannya. Setelah ada sejumlah permintaan yang lebih besar, produk memerlukan teknik produksi yang lebih intensif kapital. Pada akhirnya ketika produk menjadi dewasa dan standar, proses produksi menjadi rutin dan tenaga kerja yang kurang terampil dapat memainkan peranan yang lebih besar. Hirsch juga menerangkan lokasi produksi dengan mengaplikasikan teorema Hecksher-Ohlin pada siklus tersebut untuk produk yang baru, tumbuh dan dewasa.

\section{Vernon: Model Siklus Produk}

Raymon Vernon berpijak pada teori keunggulan komparatif untuk menciptakan hipotesanya sendiri, yaitu hipotesa "siklus produk". Menurut Vernon, pembuat produk-produk baru harus berada dekat dengan pasar sehingga mendapatkan keuntungan berupa umpan balik dari konsumen, yang bermanfaat dalam modifikasi produk dan pelayanan. Vernon menekankan bahwa inovasi itu sendiri dibantu oleh kedekatan dengan siapa yang yang membutuhkan inovasi. Jadi, baik inovasi maupun produksi cenderung akan dikonsentrasikan di negara-negara dimana diketahui ada kebutuhan dan keinginan baru. Vernon secara implisit menolak bahwa 
proporsi faktor dan biaya komparatif menentukan lokasi produksi dan ekspor produk-produk baru. la memprediksikan produk-produk baru akan diproduksi pertama kali di, dan akan diekspor dari, negara dimana produk tersebut pertama kali diminta. Hanya setelah produk tersebut menjadi dewasa dan standar, produksinya bergerak ke lokasi yang biayanya lebih rendah.

Hipotesa Vernon ini mempunyai implikasi inovasi produk-produk baru cenderung akan muncul di negara-negara yang pendapatannya relatif tinggi di mana kemungkinan besar terdapat pasar yang potensial. Di negara-negara yang mempunyai konsumen dengan pendapatan yang relatif tinggi, permintaan konsumen menjadi lebih terdiferensiasi dan hal ini dapat mendorong inovasi produk-produk baru. Sebaliknya, munculnya produk-produk yang baru dapat merangsang keinginan masyarakat untuk membeli (World Investment Report, 1999: 193).

Ketiga model perdagangan yang dianalisa dari segi teknologi akan menjadi lebih jelas apabila diaplikasikan pada Amerika Serikat. Ketiga model tersebut mempunyai prediksi yang sama, yaitu Amerika Serikat akan menjadi eksportir produk-produk baru. Namun alasan di balik prediksi tersebut pada masing-masing model berbeda. Posner menyusun modelnya dengan asumsi teknologi yang digunakan untuk memproduksi produk baru hanya tersedia di Amerika Serikat, sementara Hirsch berpendapat bahwa teknologi tersedia di manapun tetapi menggunakan secara intensif tenaga kerja terampil yang berlebih-lebihan di Amerika Serikat.

Vernon beranggapan bahwa produk baru diproduksi di Amerika Serikat supaya dekat dengan pasar walaupun biaya untuk memproduksinya di Amerika Serikat lebih tinggi dibandingkan lokasi manapun. Inti dari hipotesa Vernon yang diaplikasikan pada AS juga merupakan suatu pemikiran bahwa produk-produk baru dibutuhkan untuk memuaskan keinginan konsumen berpendapatan tinggi atau untuk mengekonomiskan biaya tenaga kerja yang ditanggung produsen. Karena Amerika Serikat pasca perang dunia memimpin dalam hal pendapatan per kapita dan upah relatif maka inovasi pun terkonsentrasi di AS. Vernon (1979) mengakui bahwa kondisi tersebut pada akhir-akhir ini sudah berubah, yaitu upah dan pendapatan negara-negara lain telah mengejar AS. Pada saat yang sama, bahan baku telah menggantikan tenaga kerja sehingga fokus inovasi kini tidak lagi untuk mengurangi biaya tenaga kerja.

\section{ARAH PERKEMBANGAN TEKNOLOGI}

Perkembangan teknologi mengalami percepatan terus-menerus pada dekade 1980 dalam tiga arah, yaitu: (1) perbaikan aplikasi yang ada, misalnya lebih cepat, lebih murah, dsb; (2) ekspansi ke dalam aplikasi baru, 
misalnya dari pabrik ke desain, logistik, distribusi, perencanaan, dan rantai suplai; dan (3) customising, yaitu versi tepat guna dari teknologi manufaktur maju menjadi tersedia untuk sektor-sektor tertentu, sesuai ukuran perusahaan dan rentang harga (J. Bessant, 1991; Bessant dan Rush, 1995: 104) ${ }^{4}$

Menurut Acemoglu arah perubahan teknologi ditentukan oleh ukuran pasar. Jika pekerja terampil lebih banyak tersedia, pasar untuk teknologi yang bersifat pelengkap ketrampilan menjadi lebih besar. Implikasinya, lebih banyak penemuan-penemuan di bidang teknologi yang melengkapi ketrampilan, dan teknologi baru akan bersifat melengkapi ketrampilan (Acemoglu, 1998: 1082).

Zoseph Zeira (1998: 1092) lebih menekankan faktor upah dan suku bunga sebagai penentu jenis teknologi yang dipilih. Upah yang lebih tinggi akan mendorong adopsi teknologi industri, karena dapat menghemat tenaga kerja, sedangkan tingkat upah yang lebih tinggi akan mengurangi adopsi teknologi.

Rosenberg (1996) dan Wright (1997:1562) menjelaskan bahwa banyak yang meyakini arah perkembangan teknologi hampir pasti tidak dapat ditentukan. Hal ini karena beberapa sebab; (1) Para penemu teknologi tidak dapat meramalkan seberapa jauh perbaikan teknologi di masa depan; (2) Cakupan aplikasi suatu penemuan teknologi baru tergantung pada perkembangan teknologi pelengkap yang tidak dapat diprediksi; (3) Penggunaan penemuan teknologi tersebut di masa depan merupakan bagian yang kompleks suatu sistem yang saling tergantung yang tidak dapat diperkirakan sebelumnya.

Karena arah perkembangan teknologi yang tidak dapat ditentukan, Gavin Wright menegaskan bahwa aturan main dalam perubahan teknologi adalah "bounded rationality" (Wright, 1997: 1562). Ketidakjelasan arah perubahan teknologi ini juga menimbulkan resiko dan berkurangnya kemanfaatan investasi riset untuk menemukan teknologi yang baru. Menurut Wrigth, masalah resiko dan ketepatgunaan dalam investasi riset untuk menciptakan teknologi baru bisa dikurangi dengan struktur kelembagaan spesifik, yaitu kekuatan pasar swasta, program persyaratan pemerintah, perlindungan hukum untuk hak cipta intelektual, kerjasama penelitian non-profit, dan diversifikasi portofolio (Wright, 1997:1560).

\footnotetext{
4 J. Bessant, Managing Advanced Manufacturing Technology: the Challenge of the Fifth Wave, NCC-Blackwell, Manchester, 1991, dikutip dari J. Bessant and H. Rush, 1995, "Building bridges for innovation: the role of consultants in technology transfer", Research Policy, Vol. 24, No. 1, January, hal. 104
} 


\section{PENUTUP}

Perubahan lingkungan kompetisi pada tahun-tahun terakhir ini membuat fokus perkembangan teknologi dan besarnya peranan pemerintah di masing-masing negara menjadi berlainan. Negara-negara industri secara umum memfokuskan dan berlomba-lomba untuk mencapai batas-batas inovasi mereka, dan mencoba untuk memperbaiki sistem inovasi nasional. Disisi lain, negara-negara berkembang pada umumnya lebih fokus untuk mengadaptasikan teknologi yang ada secara lebih efektif. Walaupun demikian, perusahaan-perusahaan di sejumlah negara berkembang juga menjadi inovator, terutama untuk ceruk-ceruk pasar yang masih memberikan potensi (World Investment Report, 1999: 196).

Pengamatan proses industrialisasi amat jelas tidak bisa mengabaikan arah perkembangan teknologi. Dengan demikian teori-teori mengenai teknologi menjadi sangat relevan kalau para peneliti mengenai industrialisasi ingin memperoleh gambaran yang baik mengenai prosesproses yang berlangsung. Ketertinggalan negara sedang berkembang dalam bidang ekonomi sebenarnya dapat ditelusuri dari ketertinggalan di bidang teknologi ini. Sekarang ini sedang sangat popular soal "knowledgebased economy" (KNE). Diskusi mengenai KNE berkenaan dengan pengembangan perekonomian suatu negara sudah barang tentu sangat berkaitan dengan persoalan-persoalan (hubungan) antara teknologi dan ekonomi. Teori-teori yang dibahas di depan akan memiliki relevansi yang tinggi dalam melihat persoalan tersebut, khususnya bagi negara sedang berkembang.

\section{DAFTAR PUSTAKA}

Acemoglu, Daron .1998, "Why Do New Technologies Complement Skill? Directed Technical Change and Wage Inequality," The Quarterly Journal of Economics, November, hal. 1082.

Bessant, J. 1991. Managing Advanced Manufacturing Technology: the Challenge of the Fifth Wave, NCC-Blackwell, Manchester.

Bessant, J. and H. Rush, 1995, "Building bridges for innovation: the role of consultants in technology transfer", Research Policy, Vol. 24, No. 1, January, hal. 104.

Deardorff, Alan V. 1996, "Testing Trade Theories and Predicting Trade Flows", dalam R.W. Jones and Peter B. Kenen (eds.), Handbook of International Economics, International Trade, Elsevier, Amsterdam, hal. 493-495. 
Dixon, Huw. 1997, "Controversy: The Source and Measurement of Technical Change", The Economic Journal, 107, September 1997, pp. 1518.

Eaton, Jonathan and Samuel Kortum, 1999, "International Technology Diffusion: Theory and Measurement", International Economic Review, Vol. 40, No. 3, hal. 537-538.

Rosenberg, Nathan. 1982, Inside the Black Box; Technology and Economics, New York, Cambridge University Press, 247.

. 1996, "Uncertainty and Technological Change." dalam The Mosaic of Economic Growth (ed. Ralph Landau, Timothy Taylor and Gavin Wright), Stanford, CA: Styanford University Press; Ruttan, Vernon W. 1997, "Induced Innovation, Evolutionary Theory and Path.

Dependence: Sources of Technical Change", The Economic Journal, 107, September, hal. 1520.

Williams, R. and D. Edge, 1996, "The social shaping of technology", Research Policy, Vol. 25, No. 6, September, hal. 871-865-866.

World Bank, World Investment Report 1999, Washington D.C. hal. 193.

Wright, Gavin.1997, "Towards A More Historical Approach To Technological Change," The Economic Journal, 107, September, hal. 1562.

Zeira, Joseph .1998, "Workers, Machines and Economic Growth," The Quarterly Journal of Economics, November, hal. 1092. 